\title{
Soldiers, Artisans, Cultivators and Revolutionaries: The Movement of Sikhs in the Indian Ocean
}

\author{
Anjali Gera Roy, Indian Institute of Technology, Kharagpur
}

\section{Introduction}

The geography of Punjab, a land-locked region divided between India and Pakistan, makes it an unlikely player in oceanic sojourns. But imperial interventions in Punjab in the middle of the $19^{\text {th }}$ century triggered movements from Punjab that inserted this region in the littoral narrative of the Indian Ocean. Unlike the movements of lascars and traders from coastal regions, which have been central to the revisionist histories of the Indian Ocean, Sikh migrations from Punjab have not featured in oceanic dialogues. The absence of Sikhs in Indian Ocean studies is largely due to the silence of Sikh soldiers, skilled craftsmen and cultivators with largely rural roots who were uprooted to strange lands. The confusion of Sikhs with Hindus, Muslims, and even Afghans, in the colonial era, as well as the classification of Punjabi Muslims as Pakistani in the post-colonial, further complicates the Sikh migration narrative. ${ }^{1}$ Falling between economic, military, cultural and labour histories, these movements have remained largely undocumented. In the absence of written documentation, the buried narrative of Sikh journeys, therefore, must be reconstructed through statistical data in colonial records, anecdotal references in imperial texts, memoirs of colonial administrators, oral histories, photographs, interviews and Punjabi folk genres. Drawing on a wide range of official and unofficial

\footnotetext{
${ }^{1}$ Thomas Metcalf (2007) points out that the term Sikh was used in South East Asia as a floating signifier to refer to anyone who was seen as possessing certain attributes and that anyone with a certain physique and wearing a turban could pass as Sikh. He mentions Jones-Vaughan's comment about half of the Selangor Police Force not being Sikh but Pathan, hailing mainly from Peshawar.
}

PORTAL Journal of Multidisciplinary International Studies, vol. 9, no. 1, January 2012. Indian Ocean Traffic Special Issue, guest edited by Lola Sharon Davidson and Stephen Muecke. ISSN: 1449-2490; http://epress.lib.uts.edu.au/ojs/index.php/portal PORTAL is published under the auspices of UTSePress, Sydney, Australia. 
historical sources, this essay argues that twin developments in Punjab, namely the construction of Sikhs as 'a martial race’ and their integration in the imperial capitalist economy, connects the movements of soldiers and policemen to Shanghai, Hong Kong, the Straits Settlements and Kenya with those of skilled artisans to Mombasa and Uganda.

Memoirs of colonial administrators, such as John W. Cell (2002), James Douie (1916), Herbert Edwardes (1851), S. S. Thorburn (1876), Malcolm Darling (1928) and others, can serve as valuable documents on 'the Punjab school' by providing the rationale for imperial policies in the region, the problems the officials encountered in implementing them, and an assessment of their success or failure. Animated by the reformist rhetoric characterizing the civilizing mission, these documents constitute justifications by young officers for colonialist strategies of survey, measurement, revenue collection and improved irrigation and cultivation undertaken with the objective of propelling Punjab into modernity. Along with British administrators' reports and memoirs, colonial documents such as the Enlisted Record below constitute valuable sources of information.

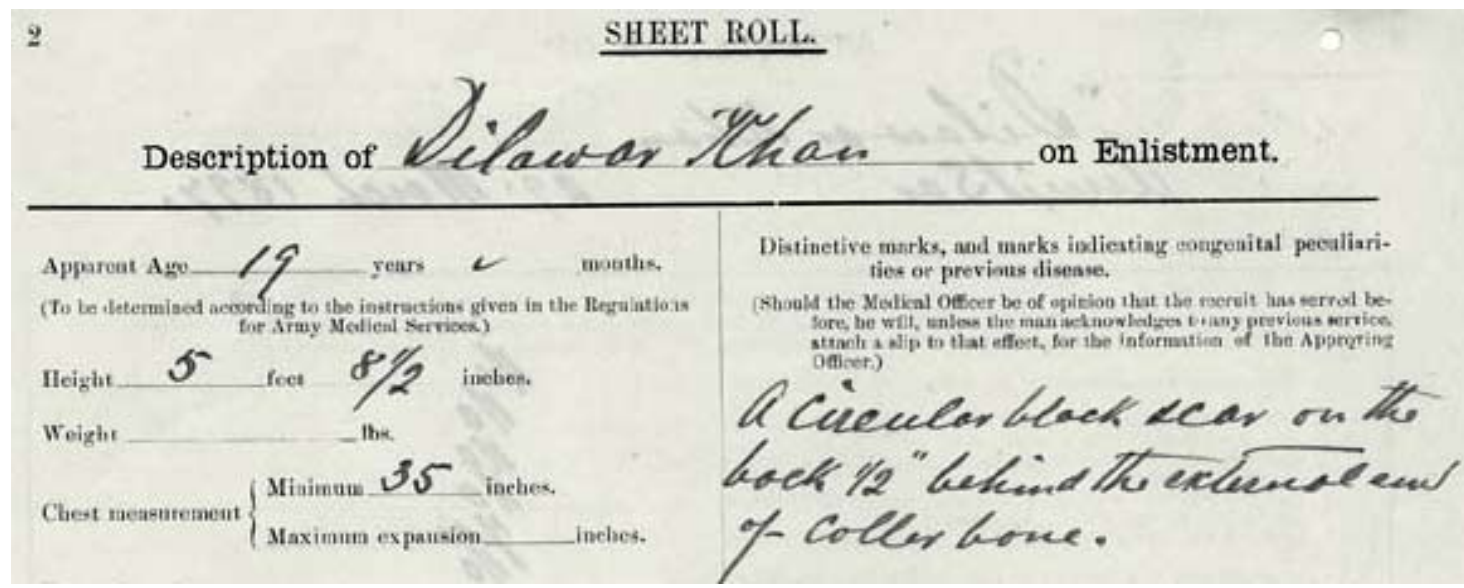

Enlistment record of Dilawar Khan dated March 29 1897. Dilawar enlisted with the Hong Kong and Singapore Royal Garrison Artillery (HKSRGA) at the age of nineteen. (Source: Moving Here Catalogue.)

Punjabi folksongs also constitute an unexpected archive of movements from Punjab. If the opening boli or call of Bhangra, ${ }^{2}$ the Punjabi harvest dance, naturalizes the Sikh narrative of mobility and their mobile subjectivities, Punjabi folksongs provide an important lead into the place, duration and nature of their sojourns abroad. ${ }^{3}$ Amarjit

\footnotetext{
${ }^{2}$ Bareen barseen khatan giya si/ Ki khat ke lihanda (You were away a dozen long years in search of a living/ What did you earn and bring back home?)

${ }^{3}$ In the following folksong, immortalized by Punjab’s singing legends Surinder and Parkash Kaur in the
} 
Chandan mentions that the imperial state co-opted Punjabi folksingers to encourage overseas recruitment on the eve of the First World War. But the popular folksong he cites equally fits earlier imperial exhortations to Punjabi young men to join the army:

\author{
bharti ho ja wey \\ aithey khaweynga wey sukki roti \\ othey khaweynga biscoot \\ pattooa biscoooot \\ bharti ho ja wey... \\ aithey paweynga khaddar dey leerey \\ othey paweynga soot, pattooa soooot \\ The recruits are at your door step \\ Here you eat dried roti \\ There you'll eat biscuits ... \\ Here you are in tatters \\ There you'll wear a suit ...
}

\title{
Drivers of Punjabi migration
}

Notwithstanding the Bhangra boli's confirmation of its economic imperative, Punjabi

migration does not strictly fall into the narrative of indenturement. ${ }^{4}$ Distinguishing

Punjabi migration from those from other parts of India, Shinder Thandi opines that

'Punjabi migration really commenced during the final quarter of the 19th century' and

1940s, a young soldier returning home after a long sojourn continues to tease a village belle until she realizes that he is none other than her absent husband:

Soldier: Sadke sadke jandiye mutiare ni kanda chuba tere pair bankiye naare ni Oh young lass trundling down the road! A thorn has pricked your foot

Young Woman: sadke sadke jandiye siphaiya we kanda chuba mere pair bankiye rahiya we Oh young soldier marching down the road! A thorn has indeed pricked my foot, oh young wayfarer

The motif of young Sikhs leaving their newly married wives in the care of parents and returning home, sometimes after a gap of a decade or more, runs through the life stories of most pioneer Sikhs in Africa, Australia, North America, Canada and Malaya uploaded on Sikh websites, as well as in the memoirs and ethnographic studies published by their descendants. Most pioneers were married either in childhood or before their sojourns abroad and could afford to return home only after a gap of several years to visit wives and children left in the care of the family. The tradition of sons returning to the places of migration with their fathers was followed for at least a generation, if not more. The wives of Munshi Ram Aggarwal and Kala Singh, the East African Sikh pioneers, did not accompany them to Nairobi, but two of Ram's sons, Lekh Raj and Puranchand, joined their father in Africa. The family business in India was left in the hands of the eldest son, Wa'liati Ram, corroborating Tatla's thesis about younger sons being encouraged to travel abroad to prevent subdivision of land holdings and property following the Land Settlement Act (2004). Kala Singh, who is alleged to have had a Masai wife, eventually returned to the wife he left behind, in Maur Mandi, at the end of his life.

${ }^{4}$ Hans Raj Aggarwal, the grandson of the Hindu East African pioneer Munshi Ram Aggarwal, recollects a visit by the then Governor of Nairobi offering his grandfather acres of land at a dirt cheap price and Munshi Ram declining it politely by replying: 'we are only here for a few years, for business purposes. We don’t intend to settle. We’re well off at home’ (Aggarwal East African Sikh Heritage, n.p.) . 
regards it as 'very much a product of the strategic and influential position which Punjab acquired within the British Empire’ (2006: npg). Punjab historians, such as Ian Talbot (2004, 2007), David Gilmartin (2004), Darshan Singh Tatla (1995), Thomas Metcalf (2003) and Tan Tai Yong (2005), are divided between situating Sikh movements either in labour histories, by privileging the construction of Punjab as the granary of the Empire, or in military histories by highlighting the colonial production of Punjabis as 'a martial race’ (Metcalf 2007). If the reconstruction of Punjab’s agrarian history by Talbot, Gilmartin and Tatla has thrown new light on socioeconomic transformations triggering labour migrations, the tracing of its military history by Metcalf and Yong has illuminated the relationship between the construction of Sikhs as a martial race during the British empire and Sikh mobility. Tatla concludes that the socioeconomic transformations in Punjab produced a 'culture of mobility' that 'predisposed the inhabitants to the unsettling process of overseas migration' (2004: 46-47).

Punjab historians have also exposed the Janus face of British policies in Punjab and highlighted the imperialist self-interest couched in a language of paternalist concern. They have demonstrated that a number of factors, such as the construction of the Sikhs as 'a martial race' after 1857 and their preferential recruitment in the British army; the establishment of canal colonies in the 1870s and the resettlement of peasants and retired army men from densely populated regions in Punjab in the new colonies; the subsequent integration of Punjab in the colonial capitalist economy through an elaborate system of telegraphs and railways; and the paradoxical increase of rural indebtedness and prosperity in Punjabi villages completely transformed Punjab’s geography and economy.

The production of Sikhs as 'a martial race' after the Anglo-Sikh wars was followed by their resignification as peasants or skilled artisans in the decades that followed. In both cases this was impelled by a complex colonial logic designed to serve larger imperial interests. ${ }^{5}$ The deep conviction of the British about 'the martial prowess of the Sikhs' flowing out of 'their religious observances or beliefs,' as Harjot Oberoi has pointed out (1994: 361), illustrates how pseudo-scientific theories of race could be superscribed on traditional caste hierarchies and ritual formations, such as the Khalsa Sikh, to serve colonial economic imperatives. The convergence of physiognomy and the colonial

\footnotetext{
${ }^{5}$ Darshan Singh Tatla (1995) has pointed out that the perception of Sikhs as aggressive led to their classification as 'undesirable' and unfit for manual labour on the plantations in Fiji, Trinidad and Guyana.
} 
construction of the martial race resulted in the preferential recruitment of Punjabis or Sikhs in the police force. ${ }^{6}$ Gilmartin has argued that even the Punjabi 'village' and the Punjabi ‘villager' are imperial constructions (1995: 70). Imperial stereotypes of the Sikh soldier and Punjabi villager may be viewed as a classic illustration of Wallerstein's (1994) world system theory about the emergence of global capitalism in the 14th century in which the labour of the periphery was put in the service of the creation of core capital with semi-peripheries serving as conduits. ${ }^{7}$

Rajit Mazumder (2003) challenges the official justification of the establishment of canal colonies as easing demographic pressure on the densely populated districts of central Punjab by arguing that their primary objective was to obtain financial returns from investments. ${ }^{8}$ Similarly, Talbot (2007) focuses on the Janus face of British imperialism by showing that the transformative potential of the social engineering in the canal colonies was set back by the subsequent restitution of customary law in Punjab. However, it is Veena Oldenburg who unmasks the strategic misalliance of land reforms with customary law through which the system of private property and ownership transformed the concept of the Punjabi village while increasing rural indebtedness (2002). Oldenburg is unambiguous in her attribution of the impoverishment of the Punjabi peasantry to the displacement of the system of community ownership by capitalist ownership and of the Sikh revenue system by the imperial. While Mazumder, connecting military considerations with agrarian developments, argues that receipt of land grants made the recruited soldiers perceive the state as beneficent, Oldenburg calls attention to the irony of the filial connection between the peasant and the soldier, pointing out that one son in Punjabi families was made to bear the burden of the privileges earned by the other, who in turn served as fodder for the army (Oldenburg 2002; Mazumder 2003: 64).

Metcalf contends that the imperial connections between the dispersed sites of Sikh migration were forged by colonial officials’ Indian connections and interactions with

\footnotetext{
${ }^{6}$ The stipulation of a height of 5.10 and $343 / 4$ chest measurement as the eligibility condition for military recruitment displayed a distinct bias for Punjabis, who are taller and better built than other Indian ethnic groups.

${ }^{7}$ Tatla's thesis about the integration of rural Punjabis in a global economy is corroborated by an aborted plan for the construction of a transnational trade network through the resignification of Aroras and Khatris as petty shopkeepers (2004).

${ }^{8}$ He quotes Imran Ali to contend that the state's real motivation for canal construction was to entrench itself in rural society by buying the loyalty of those given grants (Mazumder 2003: 66-67).
} 
Sikh soldiers producing a 'distinctive policing strategy connecting India with the colonies from the 1870s to the First World War' (Metcalf 2007: 103). The periodic returns of Punjab officials to Punjabi villages to recruit soldiers or policemen demonstrate that 'India was not simply a colonial territory but itself a centre of Britain's imperial authority’ (Metcalf 2007: 103). Their requests for Sikh soldiers were motivated as much by their perception of Sikhs as 'brave, strong, vigorous, and well suited to the rough life and exhausting climate (Metcalf 2007: 117) as by negative stereotypes of other natives. Thus, it was India's strategic position within the Empire and the prestige of the Punjab school in colonial administration that connected Punjab to the rest of the Empire.

While privileging labour or military histories, most scholars make a perfunctory reference to the fact that the earliest movement from Punjab was that of exiles. After the end of the Anglo-Sikh war in 1848-49, the young Prince Duleep Singh was banished to England and Nihal Singh (Bhai Maharaj Singh) was deported to Singapore. ${ }^{9}$ This history of the forced migration of exiles and convicts that is older than that of the military disrupts the homogenous discourse of Sikh migration as a reward to Sikhs for their loyalty to the British. Karnail Singh Sandhu, in Sikhs in Malaysia (2008), and Rajindar Singh Bedi, in The Earliest Arrival of Sikhs in Malaya (2001), demystify the Sikh recruitment theory by arguing that the first Sikhs to arrive in the Straits Settlements were political prisoners from Punjab rather than soldiers. They assert that both officers and soldiers of the annexed Punjab’s army deemed dangerous for the East India Company were deported to the penal colonies.

\section{Hong Tou A-San in Cheen}

Echoing Metcalf's argument, Arunajeet Kaur's comprehensive Master's thesis on 'The Role of Sikhs in the Policing of British Malaya and the Straits Settlements (1874-1957)' relates the Sikh migration to British Malaya and the Straits Settlements as Sepoys to their construction as 'the martial races' after the 'Mutiny' of $1857 .{ }^{10}$ Kaur points out that proximity, tropical climate, and the positive tales told by returning Sikhs made

\footnotetext{
${ }^{9}$ An anonymous source alleges that documents about Sikh soldiers in the British army who played a dubious role in the Anglo-Sikh wars and were deployed in the Opium Wars in Shanghai since 1829 have been suppressed in both imperial and Sikh histories. However, Jackson (2012), while acknowledging the presence of Indian soldiers in the First Opium War, believes that Sikhs were not involved until the Second Opium War. Mukherjee and Qin, on the other hand, trace their movement to the late 1880s (2009). ${ }^{10}$ Kaur's revised thesis has subsequently been published as a book Sikhs in the Policing of British Malaya and Straits Settlements (1874-1957) (2009).
} 
Cheen (including Malaya, Singapore and Hong Kong) favoured destinations as compared to vilayat or Britain. ${ }^{11}$

Kaur's exclusion of Shanghai in 'Cheen' is surprising considering that colonial military records and photographic evidence from around 1860 of Sikhs resting against bombed out buildings confirm the Sikh presence in the Ludhiana Regiment sent to Shanghai to quell the Taiping Rebellion in $1851 .^{12}$ Bickers et al. ascribe the twenty-fold rise of the Indian population in Shanghai between 1885 to 1915 to the recruitment of Sikhs in the Shanghai Municipal Force (2000: 59). The Shanghai International Police Force (established in 1864) is reported to have expanded over the years (Jackson 2012) to include a Sikh Branch (established in 1884) consisting of officers who retired or were left from Sikh military detachments in China. ${ }^{13}$ On the outbreak of the Boxer Rising in 1900, troops of the $14^{\text {th }}$ Sikh Regiment are believed to have sailed from Bombay to Shanghai via Singapore and Hong Kong and returned via Taku in $1902 .{ }^{14}$ The transnational nature of Shanghai connections is reinforced by the fact that many retired Sikh soldiers from Shanghai or Hong Kong stopped over here on their way to Vancouver or Fiji. It is from here that they boarded the Komagata Maru in 1907 for the West Coast of the USA and Vancouver or travelled elsewhere. ${ }^{15}$ The role played by Shanghai and Hong Kong Sikhs in producing the myth of economic prosperity among their fellow villagers that catalyzed their desire for exploration has been underestimated. It was from the Hong Kong Sikhs, who visited Canada in 1897, that the lore of the dream of foreign lands was disseminated in Punjab.

\footnotetext{
${ }^{11}$ This is corroborated by Bhatti and Dusenbury's suggestion that the Sikhs arriving in Australia in 1890 via New Zealand may have travelled from Malaya, which supports Lopo-Dhalliwal's claim about the planter John Mackay travelling with Sikhs to Australia (Bhatti \& Dusenbury 2001; Lopo-Dhalliwal 1971: 6).

${ }^{12}$ With the passing of the Company's armies to the Crown, the senior Sikh Regiments became the $14^{\text {th }}$ (King George's Own Ferozepore Sikhs), the $15^{\text {th }}$ Ludhiana Sikhs and the $45^{\text {th }}$ of the Bengal Foot, later Indian Infantry, but were still popularly known as Rattray's Sikhs. The $15^{\text {th }}$ Sikhs saw service in Shanghai during the Second Chinese War in 1860-61, defending that city against the Taiping rebels, while all three senior battalions served in the Second Afghan War, 1878-80 (Jullunder Brigade Association, n.d, n.p.). Jackson confirms the presence of Sikh soldiers in the Second Opium War (2012: 8).

${ }^{13}$ The Chinese referred to Sikhs as Hong Tou A-San-a reference to their red turbans (Hong means red in Mandarin while Tou refers to the head). According to Jackson, 'asan is thought to derive from the Sikhs' third class social position in Shanghai, or from a transliteration of either the British exclamation "I say" or “ah, sir,” as Shanghai’s Chinese addressed the Sikhs’ (Jackson 2012: 4).

${ }^{14}$ The regiment embarked on S.S. Formosa at Bombay on August 121900 and sailed to Shanghai via Singapore and Hong Kong, disembarking on September 61900.

${ }^{15}$ For instance, Harnam Singh, who had been a 'naik' (corporal) in the $14^{\text {th }}$ Sikhs during the Boxer Rebellion, is eventually traced to Kisumu in Africa. Suneel Kumar reports: 'The Canadian Sikh delegation, which was joined by several Sikhs from Shanghai, Hong Kong, Singapore and Penang, took part in the Jaito Da Morcha of 1923-25. The Jatha started from Vancouver on July 13 1924, and reached at Jaito in Punjab, in February 1925' (Kumar 2008: npg).
} 
Hong Kong receives a mention in several studies for its historic significance, first as the earliest site of military migration, and second as an important node in transoceanic journeys to Shanghai, Australia, New Zealand, Canada and North America (Jackson 2012). It played a key role, for example, in the famous incident of the Komagata Maru since the port from which Sikhs set off for Vancouver to circumvent the restriction related to continuous journey. The Khalsa Diwan Sikh gurdwara in Wan Chai appears to have served as a transit lounge for Sikhs sailing from Kolkata to different parts of the world. It was from here that Gurdit Singh planned his operations and where many passengers lived, sometimes for years, before leaving for Canada. ${ }^{16}$ But narratives of the Sikh policemen who remained, returned, or moved on must be put together by piecing together different ends of the jigsaw puzzle. While the Sikh migration to Hong Kong is commonly traced back to Creagh's recruitment of 100 Sikhs in 1867, some sources, such as James Joseph Keezhangatte, claim that 2700 soldiers, including Sikhs, were seen at the flag raising ceremony during Captain Elliot's declaration of Hong Kong as a British occupation in 1841 (2008: 209). However, the expulsion of the Sikhs from the Police Force following the Hong Kongization of the force explains their relatively smaller number in the present (7,500 in 2006).

\section{Orang Bengali in The Straits Settlements}

The different waves of Sikh movement to Southeast Asia problematize their inclusion in Rajesh Rai (2006) and Vijay Devadas’s (2006) indentured diasporas, Claire Anderson's convict diasporas (2006), or Tan Tai Yong's military diasporas (2006). In order to construct the narrative of the migration and settlement of Sikh detainees in Malaya and the Straits Settlements, one is compelled to turn to informal Sikh chronicles such as Malkiat Singh Lopo-Dhalliwal’s Some Historical Notes (1971), Sewa Singh Gandharb’s Early Sikh Pioneers of Singapore (1986), and formal sources such as Karnail Singh Sandhu’s Sikhs in Malaysia (2008) (Lopo-Dhalliwal 1971; Gandharb 1986; Sandhu 2008).

\section{Orang Bengali as political prisoners}

Some Historical Notes (1971), a slim volume gifted by Lopo-Dhalliwal to the Sikh community to celebrate a century of Sikh presence in Malaya and Singapore, fills the

\footnotetext{
${ }^{16}$ All passengers are reported to have prayed here before the Komagata Maru departed in 1914.
} 
silence in official histories on the Sikh migration prior to $1857 .{ }^{17}$ Beginning by invoking janam sakhi references to Guru Nanak’s udasis or travels to 'Suvarna Pur' (Suwarna Bhumi) and to Sumatra, Lopo-Dhalliwal speculates that the first Sikh Guru might have visited Malacca in the $16^{\text {th }}$ century. He draws on reports of colonial officers, diaries of women travellers and newspaper reports to reproduce anecdotal evidence that testifies to the presence of political prisoners. ${ }^{18}$ The most celebrated of these was Nihal Singh or Bhai Maharaj Singh, exiled to solitary punishment in Singapore following his capture in 1849, and his disciple Kharag Singh. Karnail Singh Sandhu's account confirms the first wave of Sikh settlement in the Straits following the deportation of Sikhs opposed to British rule, first to Malacca and then to Sarawak. But he doubts if there would have been more than a few arrivals every year and suggests that the ones who followed might have been of a different category (Sandhu \& Mani 2008: 560). This contradicts LopoDhalliwal's citation of a Singapore Free Press (September 1863) report about the outbreak of one hundred 'generally powerful, daring' Sikhs brought from the Alipore jail in India. It is also silent on the anecdote about an aborted plot by prisoners to shoot the superintendent of the Singapore jail following a dispute between 'Rawdasee' [Ravidasi] and ‘Majabee’ [Mazhabi] Sikhs reported by Lopo-Dhalliwal (1971). While conceding that some discharged Sikh convicts might have decided to settle in The Straits Settlement, Sandhu categorically states that no family in Singapore or Malaysia can trace its origins to any of them (Sandhu \& Mani 2008: 560). ${ }^{19}$

Lopo-Dhalliwal's commemorative volume (1971), based on oral and undocumented Sikh sources, expresses a disagreement on accepted historical details. For example, he corrects the commonly held view of Speedy's arrival in 1874 (Winstedt 1945; Gullick 1953) by predating it by a year on the authority of a Sikh chronicler. ${ }^{20}$ Similarly, his advancing the Sikh arrival in Southeast Asia by nearly half a century to 1819 complicates the narrative of the migration of Sikh policemen through allusions to

\footnotetext{
${ }^{17}$ Nihal Singh went blind and died in 1856; Kharag Singh was detained as part of the preventative measures taken by the British after the 'Mutiny' of 1857. The marginalization of Sikhs in the sections on Southeast Asia by Rai \& Devadas in The Encyclopedia on The Indian Diaspora (ed. B. Lal et al. 2006) dealing with indenturement must be attributed to their failure to account for the Sikh migration, which was one of free workers.

${ }^{18}$ Lopo-Dhalliwal draws on the accounts of the traveller Isabella Bird, the official Charles Burton Buckley and on reports in the Singapore Free Press (1971).

${ }^{19}$ However, Lopo-Dhalliwal contends that these narratives are lost partially due to the Sikhs marrying local Malay and Chinese women. He names their children, who include pioneers such as Sardar Mohan Singh, Sardar Jaswant Singh and Sardar Samund Singh of Malacca but argues that their grandchildren acquired non-Sikh names such as Babu despite being raised in Indian traditions (1971).

${ }^{20}$ Tatla dates Speedy's arrival to 1873 (2004).
} 
movements of a different nature. While his suggestion about the first Sikh settlers in Malaya being those aboard Mackay’s ship to Australia in 1837 is uncorroborated by concrete evidence, ${ }^{21}$ Bhai Maharaj Singh’s solitary confinement, Sikh insurrections at the Singapore jail in 1868 and the settlement of Sikhs released before 1873 in Perak and other states is substantiated by oral testimonies, which allude to the intermarriage of these Sikhs with local women and records of names of specific individuals born of these unions (Lopo-Dhalliwal 1971).

Due to the confusion of Sikhs with Bengalis in Malaysia through the use of the term Bengalis to refer to all non-Tamil Hindu and Muslim migrants to Malacca at the end of the $19^{\text {th }}$ century and the adoption of the ascription by Sikhs in their self-description in the 1911 census, it is difficult to estimate the exact number of Sikh migrants to Malaysia. But the 1921 census mentions 11,113 Punjabis and 1,845 Bengalis who might have included Sikhs. ${ }^{22}$ Malay language dictionaries continue to refer to Sikhs as 'orang Bengali'.

\section{Orang Bengali as Soldiers and Policemen}

Kaur's dissertation about the Sikh presence in these states and their construction as a martial race after 1857, however, must skip several pages of the Sikh travelogue that does not conform to her thesis (2003; 2009). In buttressing her argument about the British admiration of Sikh military prowess following the Anglo-Sikh wars (18361849), she fails to explore the link between Sikh insurrections, the loyalty of 13,420 men of the Punjab Irregulars from the Punjab Frontier force during the 1857 revolt and the subsequent formation of the military force of Sikh and Punjabi Muslims between May and December 1857. Relying on Abdul Karim Bagoo’s 1954 study, Academic Exercise. The Origin and Growth of the Malayan States, Kaur corroborates the presence of Sikhs in peninsular Malaya in Perak under Captain Speedy in the employ of Ngah Ibrahim, the Mantri of Larut, in September 1873. While the symmetry of Kaur's narrative is disrupted by the 'unruly' presence of exiles and political prisoners, she bypasses the earlier wave to substantiate her 'martial race' argument. She classifies the Sikh migration into three phases: the first phase (1874-1896), in which the British were

\footnotetext{
${ }^{21}$ Margaret Allen traces this movement back to Otim Singh who left Moga for Sumatra in 1881 and arrived in Australia five years later (2008).

22 'The generic name given by Malays to Indians other than Tamils is "Bengali” and under this head come the Dogra, Sikh, Pathan, Panjabi Mussulman, Kashmiri, Waziri, Rajput, Afghan, Behari, and all other breeds of men from India who are either "Kling Hindu” or "Kling Islam”' (Lopo-Dhalliwal 1971: 1-2).
} 
trying to assert imperial authority; the second phase (1896-Second World War), which entailed the British government reorganizing colonial policing to focus on civilian needs and crime control and that coincided with the formation of the Malay States; and the third phase (1948-1960) characterized by increasing breakdown. However, focusing on migrations after 1873, she is forced to exclude the prehistory of Sikh migration to the Straits Settlements, for information on which one must turn to the less academic Some Historical Notes (Lopo-Dhalliwal 1971). The exile of political prisoners to Singapore jails after the Anglo-Sikh wars and 'the Mutiny’ of 1857, and the recruitment of Sikhs after 1857, are not really contradictory because they are both based on the representation of Sikhs as warriors in pre-colonial and colonial narratives (Yong 2005).

Kaur's attribution of the militarization of Sikhs to imperial economic imperatives in the Malayan Peninsula corroborates Tatla's thesis about the integration of both Punjabi soldiers and cultivators in the international economy (1995). Her point about the recruitment of loyal strangers to contain indigenous factions in Malaya who conflicted with British economic interests illustrates the British management of the colonial economy through an effective integration of different kinds of colonials into the world system. The movement of Sikhs in the Indian Ocean is activated by the colonial construction of different 'native' populations as industrious, lazy or martial (Metcalf 2007). ${ }^{23}$ As Kaur points out, the construction of Sikhs as 'the martial races' and of Malays and Chinese as unfit for the policing of Malaya led to the large scale recruitment of Sikhs into the police force from 1873 to 1947 . The return of Speedy and Walker, who had the experience of leading Sikhs during the 1857 Mutiny, to Punjab in search of 'pure' Sikhs, accounts for the large Sikh presence in Malaya until they faced competition from the Indian army in 1895.

\section{Kala Singha in Africa}

In contrast to that to Southeast Asia, the Sikh movement to East Africa, straddles both the military migration of Southeast Asia and labour migration elsewhere. In contrast to the Jat Sikhs recruited into the army and resettled in the canal colonies or who migrated to Vancouver or California, a different Sikh subject, belonging to the lower castes of ramgariha (carpenter), lohana (blacksmith) and mistry (mason) and also chamar

\footnotetext{
${ }^{23}$ McLeod's idea of the Sikh's evolution into a martial consciousness by the sixth Guru to accommodate the Jats, who were of a militant tradition, has a bearing here (2003).
} 
(leatherworkers), came to be integrated into the imperial world system through these castes’ production as skilled artisans largely due to the arbitrary strategies deployed by colonial officers such as Maquire and Lugard. ${ }^{24}$

Metcalf views the 'almost reflexive turning to India and to Indians by such men as Lugard and Wilcocks' as testifying to 'the power of the idea of India as a centre of crafts, skills and peoples who could be drawn upon to make empire more efficient and economical' (2007: 124). H. H. Johnston requested 'for Sikhs, and Sikhs alone' [50 raised to 70 later], preferably from his own 'raw Sikhs,' in 1891, and himself returned to recruit in Punjab in 1895. Like Walker, who took a recruiting trip to the Punjab countryside, Captain C. M. Maguire preferred 'trained and disciplined' Sikh troopers directly from the Indian army (Metcalf 2007: 115). However, Maquire’s selection of 49 Mazbi, 'or lower-class Sikhs, true Mazhabis, not Lohanas or Ramdasis,' from two premier battalions on being informed that they 'were less particular as to the food given them than Jat Sikhs' (Metcalf 2007: 116) accounts for the practical considerations that altered the caste composition of the army as well as the preponderance of lower class Sikhs in Africa. C. A. Edwards got twenty Sikhs from five regiments to sign for service in 1894 by making sure that they were 'good' Sikhs with no criminal records, even though they might have belonged to lower ranks in the army. Similarly, it was on Lugard's strategic request in 1900 for 'the so-called skilled labour viz., clerks, artisans, engineers, and pilots, etc.' on grounds of British Indians 'being of a more efficient type than those available in Africa' that ten clerks and twenty eight transport attendants were transported under Carrigan in 1905 (Metcalf 2007: 23). ${ }^{25}$ Blacksmiths were also included as they 'had already proved invaluable in teaching the natives how to use and repair carts, break in oxen to draught work, and tend animals’ (Metcalf 2007: 124).

Sikh policemen and artisans transported to Africa frequently emerge in the memoirs of colonial officers as footnotes to the heroic saga of imperial adventures, either as helpers in the accomplishment of the colonial mission or as splendid or amusing stereotypes. These memoirs are invariably cast in the Kiplingesque mould of good and bad natives produced by the colonial gaze. Adela Quested's gaze on the punkahwallah’s hourglass

\footnotetext{
${ }^{24}$ The reference to Jats, the favoured caste in the rehabilitation of canal colonies, occurs in Inder Singh Gill's account of his migration in 1922, following that of his uncle Nahar Singh Pangli, from Jundiali Ludhiana district in 1915 (he was probably one of the clerks brought by Carrigan).

${ }^{25}$ This followed the turning down of his earlier request for jemadars to lead Hausa and Yoruba troops.
} 
figure in E. M. Forster’s A Passage to India (1998) returns in Karen Blixen’s portrayal of Pooran Singh 'by the forge, bared to the waist,' in Out of Africa as 'incredibly slight and nimble, with the Indian hourglass torso' (1993: 333). Pooran Singh, the 'Fundee of the farm, which means an artisan of all work, carpenter, saddler and cabinet-maker as well as blacksmith,' in Blixen's novel, epitomizes the imperial stereotype of the Sikh. Her description of Pooran Singh, who 'behaved altogether like a man who is himself being burnt at the stake, or like some chafed over-devil at work,' belongs to the best tradition of imperialist prose. Later, she admits that Pooran Singh 'was no devil but a person of the meekest disposition' and that it 'was a very fine, proud sight, to watch him tiring a wheel' (1993: 333-35). If Blixen borrows Kiplingesque imagery to describe the Fundee on her farm, John Bate, in Wheels Over Black Cotton (1978), steals his character’s name to describe ‘the mechanically minded Gunga Din’ Lal Singh, who resembled 'a wild Afghan tribesman during working and only needed a long rifle to complete the illusion' (1978: 31). Like Blixen, his gaze lingers on 'him squatting on his haunches, gazing with Asiatic reverence, or bloody-minded at the entrails of a motorcycle bleeding to death on the floor depending on the end whether he had traced the trouble’ to mythicize the Sikh (Bate 1978: 31-32). Beryl Markham, in West with the Night, describes Bishan Singh as 'one of Kipling's elephant boys,' who remained to her 'a man of mystery, without age or youth, but burdened with experience, like the wandering Jew’ (1984: 61).

Despite their being exoticized, Blixen's mythologized Pooran Singh, who works like a maniac at his forge, Patterson's five Sikh carpenters, led by Natha Singh, who have a narrow escape through suspending a ladder that proves to be providential, or Bate's motorcycle expert Lal Singh, who miraculously produces spare parts out of nowhere, come across as exotic or comic figures. Without Kipling's deft manipulation of point of view, through which Umr Singh, the trooper in A Sahib's War, articulates the Sikh voice, Foran's colonial gaze in A Cuckoo in Kenya (1936: 102-6) can only romanticize Sergeant Harnam Singh as 'a fine figure of a man' who 'upheld the best traditions of the Indian Army throughout his career in Africa' (1936: 102-6).

A comparison of colonial accounts and imperial texts with the self-narratives of Sikh pioneers in East Africa provides a glimpse into alternative migrant perspectives of the migration process. In order to reconstruct this alternative account of the movement of 
Sikhs in the late 1880s, a Sikh website called Sikhs of East Africa that has put together colonial records, memoirs of colonial officers, photographs, interviews and oral histories of pioneers and their descendants, proves to be an invaluable archive by confirming, correcting and disrupting imperial narratives of the same event. The mythical Sikh characters produced in imperial texts return in the stories and interviews of colonial officials and pioneer Sikhs uploaded on Sikh websites. Blixen’s description of Pooran Singh as 'an ascetic of the first water' who 'did not eat meat,' 'did not drink, or smoke, or gamble' makes one suspect if her investment of 'mythic qualities' in the Fundee of her farm produced the saintly Baba Pooran Singh of Kericho venerated by Sikhs (1993: 333-35). Perhaps Pooran Singh, who had set sail for India in Blixen's memoirs, returned to Kenya in the avatar of Baba Pooran Singh after visiting the family in Punjab he had not seen for years. The wounded 'splendid great Sikh' in F. Jackson's Early Days in Africa (1930), who keeps lunging at the rebellious Swahili boy despite his arm being blown off during the suppression of the revolt in 1897, is probably Jemadar Bhagwar [Bhagwan] Singh from the Ludhiana (later the $15^{\text {th }}$ ) Sikhs. Records confirm that Bhagwar [Bhagwan] Singh 'joined the Suakin Expedition in 1885, sailing for the Sudan and fighting the Dervishes at Totrek where defensive stockades were built' and whose 'gallantry and discipline saved the column from complete destruction. ${ }^{26}$ Other Sikh policemen, such as the four jemadars mentioned by Metcalf who signed up for East Africa, reappear in colonial memoirs (Metcalf 2007: 119). Sikhs like Inspector Besant Singh become the object of respect as accomplices of young colonial officers. Foran describes Besant Singh as 'a tower of strength, often saving me [Foran] from making an abject idiot of myself [himself] through over-hasty action or sheer ignorance' (1905: 102-6). He adds that Besant Singh 'was a great 'shikari,' a brave man and worthy of the highest traditions of the gallant Sikh units in the Indian

\footnotetext{
${ }^{26}$ The $14^{\text {th }}$ Ferozepore Sikhs after this served in East Africa and China. The $15^{\text {th }}$ Ludhiana Sikhs were sent to Egypt and then to Sudan, where they won battle honours at Totrek (D.S. Sandhu, n.d., n.p.). 'The 15th Sikhs joined the Suakin Expedition in 1885, sailing for the Sudan and fighting the Dervishes at Totrek where defensive stockades were built. Their gallantry and discipline saved the column from complete destruction' ('The $47^{\text {th }}$ [now the $5^{\text {th }}$ ] Regiment,' Jullundur Brigade Association, n.d., n.p.). 'In June, 1897, a party consisting of Lieutenant Macdonald, Jemadar Bhagwan Singh and fourteen men proceeded to British East Africa and joined an expedition formed to fight mutineers and other hostile elements in the Sudan. Of this small detachment Lieutenant Macdonald and one sepoy were killed and Jemadar Bhagwan Singh and three sepoys wounded. Jemadar Bhagwan Singh and three sepoys were awarded the Indian Order of Merit for continuous conspicuous gallantry in action, and the officer in charge of the expedition, Colonel Macdonald, writing about the party, stated: "This detachment fully maintained the great reputation of the 14th Sikhs and fought with such gallantry that they secured the admiration of all"' (Jullundur Brigade Association, n.d., n.p.). The party returned to the Regiment in Nowshera on May 71899.
} 
Army in which he served with honour before transferring to the Indian Police and then coming to British East Africa’ (1905: 102-6). In Kill or Be Killed, Foran also names ‘a stalwart Sikh policeman,' Harnam Singh, whose lusty shouts scared a leopard perched on his shoulders during a hunting expedition, confirming the presence of Sikh policemen in East Africa in the 1890s (1905: 53-55). Although they are seen playing second fiddle to the man eaters in J. H. Patterson's The Man Eaters of Tsavo, the 'fine powerful Sikh named Ungan Singh,' who was 'seized in his tent, dragged and eaten' finds a mention (1907: 21-24). The model police sergeant, 'who had been a "naik" (corporal) in the 14th Sikhs,' had probably served with them through the Boxer Rebellion in China. Sikh officers like Satbachan Singh, the first police officer in Kenya, were remembered by their associates for years after leaving service. ${ }^{27}$

Even though some journeys, like that of Jagat 'Macho Dogo,' predate the construction of the Uganda Railways, the Sikh military and police narrative in East Africa is imbricated with that of the railways. The Sikh pioneers, Munshi Ram Aggarwal, Kala Singha, Jagat 'Macho Dogo' and Lal Singh, came to explore the business opportunities opened by the setting up of the railways. The first police inspector in Africa, Kapur Singh, was brought over to oversee the construction of the Ugandan railways for which a large number of Sikhs from the artisan castes of ramgarihas, lohanas and mistries were recruited. Kapur Singh's secondment to work with the Kenya Police Force in 1895 following his posting in Baluchistan confirms the nexus between Land Settlement Acts, military recruitment and migration from thickly populated areas like Gagobuha near Amritsar, from which Kapur Singh hailed, as well as the Punjab experience of colonial officers who served in other colonies such as Malaya and East Africa. The policy followed in the canal colonies of rewarding Sikhs through land allotments for services rendered in the army or elsewhere appears to have been replicated in East Africa when Indian migrants working on the railways were offered land grants after the completion of the railways. Among these was the pioneer Jagat 'Macho Dogo,' hailing from a farming family. Impressed by his farm, measuring about 105 acres by the Kibo River, the British encouraged him to bring more farmers like himself to set off a chain

\footnotetext{
${ }^{27}$ It is interesting that the colonial ascriptions of Sikhs such as those surrounding Satbachan Singh, killer of lions, lover of nature, model farmer, cattle breeder and spiritual healer, should have been internalized and absorbed in family lore. Mohinder Singh Chadha highlights the role of Sikhs in maintaining law and order by recalling his uncle Labha Singh Chadha's reputation as a lion killer when he arrived from Jhelum, after serving in the police force, at the turn of the century. Labha's other brothers, Lakha Singh and Bishen Singh, who followed him, also appear in the records of colonial officers.
} 
migration with brothers, cousins and entire villages joining Sikh migrants to Africa. These communities mirrored the kin-based village communities that the colonial government had consciously reproduced in Sikh settlements in the canal colonies.

Except for those of the young and poor Jagat 'Macho Dogo' and his friend Lal Singh, from Jullunder district, who worked their way to Africa by firing the boiler on a steamer in 1892/93, the experiences of the Sikh pioneers are underwritten by both 'the culture of mobility,' which Tatla sees as characterizing the Sikhs following their resettlement in the canal colonies, and the colonial policies that forced movement. ${ }^{28}$ Gurdit Singh Nayer, a grown man of 32, set off from Lahore to East Africa in 1889 to improve his economic prospects by working as a cashier in the newly opened Bank of India and traveling to remote regions in dangerous conditions. Soon enough, he was to discover better opportunities in serving as a commission agent for artisans from his home town. Nayer diversified into the furniture business, constructed many landmark buildings in Nairobi and became a prominent figure before being forced to return to Lahore in 1932 after a huge business loss. It was his wife Damayanti who brought the children back to settle in Nairobi after spending five years in Lahore during which Nayer died. The emphasis laid by his son Trilok Singh Nayer on his parents' upper class credentials (of his father being a highly cultured man, well versed in Persian, music and theatre, and his mother being from a prominent Lahori family) disrupts the topos of poverty that undergirds migration literature.

Similarly, the imperial construction of the exploitative relationship between the Hindu bania or moneylender and the Sikh and Muslim peasants, the official reason for the introduction of the Land Alienation Act of 1900, is refuted by Oldenburg who argues for a cooperative rather than extortionist relation in the pre-colonial system between the literate Hindu record keeper and the non-literate peasants (2002). The evidence of this co-operation emerges in the strong bond between two young men from Maur Mandi in the Patiala State, Munshi Ram Aggarwal, from a prosperous Hindu bania family, and Kala Singh, from the Jat Sikh caste, who were the first to arrive in East Africa from Punjab in the 1880 s.

\footnotetext{
${ }^{28}$ Neither the Sikh pioneers who travelled to East Africa, nor all those who set sail on the Komagata Maru to Vancouver, were impelled by poverty to seek a fortune overseas because, as some historians have pointed out, few landless families could have afforded to raise the passage.
} 
Neither the imperial motif of poverty nor caste enmity but a narrative of adventure emerges as the key motivator for the journeys of these two Punjabi pioneers to Africa. Despite Hindu Munshi Ram’s greater business acumen, the sixteen year old Sikh, Kala Singh, made a larger impact on the Masai Reserve and with other indigenous people and became the ethnocultural signifier of Punjabi identity. Even after they had parted ways professionally, the friendship between the families survived time and space. Munshi Ram’s descendant, Hans Raj Aggarwal, refused to dishonour his father's associate's memory by refuting all allegations of his secret liaisons with African women.

Aggarwal's reminiscences also suggest a chain migration from Maur Mandi through the subsequent settlement of Sikhs from the village and an intersection of not only caste but also sectarian boundaries that explains the confusion of Sikhs with Hindus, and even Pathans, in the minds of their Australian or Californian hosts.

\section{Conclusion}

This essay shows that embedding divergent narratives in the frame tale of the initiating impulse for migration, namely the socioeconomic transformations in 19th century Punjab, can link apparently disconnected Sikh migration stories to different parts of the world. Instead of beginning with the places of settlement, a return to colonial policies and developments in the sending villages of central doaba districts of Punjab can explain how Punjabi hinterlands were connected to port cities. Following Sikhs from their dispersed sites of resettlement to their home villages in the districts of Amritsar, Ludhiana, Jullundur, Hoshiarpur and Ferozepore in central Punjab provides insight into the political, social, economic and cultural transformations that began the continuing overseas traffic from remote hinterlands.

\section{Reference List}

Allen, M. 2008, ““A Fine Type of Hindoo” Meets the “Australian Type”: British Indians in Australia and Diverse Masculinities,' in Transnational Ties: Australian Lives in the World, (eds) D. Deacon, P. Russell \& A. Woollacott, ANU E-Press, Canberra, pp.41-58.

Anderson, C. 2006, 'Convict Migration,' in The Encyclopedia of Indians Overseas (eds) B. Lal et al., Editions Didier Millet \& Landmark Books, Singapore.

Ashraf, Ch. M. (ed.) 1995, Officers of the Punjab Commission. NEDA Publishers, Lahore.

Bagoo, A.K. 1954, Academic Exercise. The Origin and Growth of the Malayan States. University of Malaya, Singapore.

Bate, J. 1978, Wheels Over Black Cotton. Stockwell, Ilfracombe.

Bedi, R.S. 2001, 'The Earliest Arrival of Sikhs in Malaya,' paper presented at the Colloquium on 'Indians in Penang-A Historical Perspective,' organised by the Penang Heritage Trust \& the Indian Chamber of Commerce and Industry, Penang, 22 September.

Bhatti, R. \& Dusenbery, V.A. (eds) 2001, A Punjabi Sikh Community in Australia: From Indian Sojourners to Australian Citizens. Woolgoolga Neighbourhood Centre Inc., Woolgoolga. 
Bickers, R. \& Henriot, C. (eds) 2009, New Frontiers: Imperialism’s New Communities in East Asia, 1842-1953. Manchester University Press, Manchester.

Blixen, K. 1993, Out of Africa and Shadows on the Grass. Penguin, Delhi.

Chandan, A. 1998, 'How They Suffered: World War I and its Impact on Punjabis,' paper presented at 'Across the Black Waters,' a one-day symposium at the Imperial War Museum, London, November 7. Online, available: http://apnaorg.com/articles/amarjit/wwi/ (Accessed 27 October 2009).

Cell, J.W. 2002, Hailey. A Study in British Imperialism 1872-1969. Cambridge University Press, Cambridge.

Chapman, G. 2003, The Geopolitics of South Asia: From Early Empires to the Nuclear Age. Ashgate, Aldershot.

Chin, C. 2009, 'Of Prisoners and Peacekeepers,' The Star online, Friday 15 May. Online, available: http://allmalaysia.info/2009/05/18/of-prisoners-and-peacekeepers/ (Accessed 23 October 2009).

Cohen, R. (ed.) 1995, The Cambridge Survey of World Migration. Cambridge University Press, Cambridge.

Darling, M.L. 1984 [1928], Punjab Peasant Life. With a Foreword by Sir Edward Maclagan, Oxford University Press, Milford \& Cosmo, New Delhi.

Das, R.N. 1990, 'A Nationality Issue: Ethnic Indians in Hong Kong,' in The Other Hong Kong Report 1990, (ed.) R.V.C. Wong \& J.Y.S. Cheng, Chinese University Press, Hong Kong, 147-67.

Devadas, Vijay 2006, 'The Kangani and Maistry System,' in The Encyclopedia of Indians Overseas (eds)

B. Lal et al., Editions Didier Millet \& Landmark Books, Singapore, 53-57.

Douie, J. 1916, The Panjab, North-West Frontier Province And Kashmir. Cambridge University Press, Cambridge.

Edwardes, H. 1851, A Year on the Punjab Frontier, 1848-49. 2 vols. Richard Bentley, London.

Foran, W.R. 1933, Kill or Be Killed. Hutchinson and Co., London. 1936, A Cuckoo in Kenya. The Reminiscences of a Pioneer Police Officer in British East Africa, with a Foreword by Lord Cranworth. Hutchinson, London.

Forster, E.M. (ed. O. Stallybrass with an Introduction by P. Mishra) 1986, A Passage to India. Penguin Classic, Toronto.

Gandharab, S.S. 1986, Early Sikh Pioneers of Singapore. Sewa Singh Gandharab, Singapore.

Gilmartin, D. 1995, 'Migration and Modernity: The State, the Punjabi Village, and the Partition of the Punjab,' South Asia, vol. 18 (Special Issue): 57-72.

2004, 'Migration and Modernity: The State, the Punjabi Village, and the Settling of the Canal Colonies,' in People On The Move: Punjabi Colonial, and Post-Colonial Migration, (eds) I. Talbot \& S.r Thandi, Oxford University Press, Karachi, 3-20.

Goodall, H., Ghosh, D. \& Todd, L. 2008, 'Jumping Ship, Skirting Empire: Indians, Aborigines, Australians across the Indian Ocean,’ Transforming Cultures eJournal, vol. 3, no. 1: 44-74.

Gullick, J.M.1953, 'Captain Speedy of Larut,' J.M.B.R.A.S., vol. 26, no. 3, in 1971, Some Historical Notes (Malaysian Sikhs). N.p., West Malaya.

Jackson, F. 1930, Early Days in East Africa. Edward Arnold \& Co., London.

Harrison, C.W. 1923, An Illustrated Guide to the Federated Malay States. The Malay States Development Agency, London.

Ibbetson, D. 1974, Panjab Castes. B.R. Publishing Corp., Delhi.

Jackson, I. 2012, ‘The Raj on Nanjing Road: Sikh Policemen in Treaty-Port Shanghai,' Modern Asian Studies: doi:10.1017/S0026749X12000078.

Kaur, A. 2003, The Role of Sikhs in the Policing of Malaya and the Straits Settlements. Unpublished M.A. thesis, National University of Singapore. 2009, Sikhs in the Policing of British Malaya and Straits Settlements (1874-1957). VDM Verlag Dr Muller, Saarbrucken.

Keezhangatte, J.J. 2008, 'Blue-collar Indians in Hong Kong: Imperceptible Yet Important in Hong Kong,' in Rising India and Indian Communities in East Asia, (eds) K. Kesavapany, A. Mani, \& P. Ramasamy, Institute of East Asian Studies, Singapore, pp.207-228.

Kesavapany, K., Mani, A., \& Ramasamy, P. (eds) 2008, Rising India and Indian Communities in East Asia. Institute of East Asian Studies, Singapore.

Kipling, R. 1999, 'A Sahib’s War and Other Stories,' in War Stories and Poems. Oxford University Press, London, pp.163-80.

Kumar, S. 2008, 'Linkages between the Ethnic Diaspora and the Sikh Ethno-National Movement in India,’ Faultlines, vol. 19. Online, available: http://www.satp.org/satporgtp/publication/faultlines/volume19/Article4.htm/ (Accessed 23October 2009). 
Lal, B.V. (ed.) 2006, The Encyclopedia of the Indian Diaspora. Didier Millet, Singapore.

Lopo-Dhalliwal, M.S. 1971, Some Historical Notes (Malaysian Sikhs). N.p., West Malaya.

Markham, B. 1984 [1942], West with the Night. Virago, London.

Mazumder, R. 2003, The Indian Army and the Making of Punjab. Permanent Black, Delhi.

McLeod, W.H. 2003, Sikhs of the Khalsa: a History of the Khalsa Rahit. Oxford University Press, New Delhi.

Metcalf, T.R. 2007, Imperial connections: India in the Indian Ocean Arena, 1860-1920. University of California Press, Berkeley.

Moving Here Catalogue. Online, available: WO97/5281_2 www.movinghere.org.uk/galleries/roots/.../servicerecords.htm (Accessed 26 October 2009).

Mukherjee, B. \& Qin, X. 'Lording over the Locals: When Red Turbans were a Familiar Sight,' ShanghaiDaily.com. Online, available:

http://www.shanghaidaily.com/sp/article/2009/200908/20090812/article_4103 (Accessed 26 October 2009).

Oberoi, Harjot 1994, The Construction of Religious Boundaries: Culture, Identity and Diversity in the Sikh Tradition. Oxford University Press, New Delhi.

Oldenburg, V. 2002, Dowry Murder: The Imperial Origins of a Cultural Crime. Oxford University Press, New York.

Patterson, J.H. 1907, The Man Eaters of Tsavo. MacMillan, London.

Rai, R. 2006, 'Indians in Singapore,' in The Encyclopedia of the Indian Diaspora (eds) B.V. Lal, P. Reeves \& R. Rai, Editions Didier Millet, Singapore, 176-88.

Sandhu, D. S. n.d. The Sikh Regiment. Online, available: http://www.bharatrakshak.com/MONITOR/ISSUE3-6/sandhu.html (Accessed 26 October 2009).

Sandhu, K.S. 2006, 'Sikhs in Malaysia: A Society in Transition,' in Indian Communities in South East Asia, (eds) K. S. Sandhu \& A. Mani, Institute of South East Asian Studies, Singapore, pp. 557-67.

Sandhu, K.S. \& A. Mani (eds) 2006, Indian Communities in South East Asia. Institute of South East Asian Studies, Singapore.

Sikhs of East Africa. Online, available: www.sikhheritage.co.uk/heritage/sikhhert\%20EAfrica/sikhsEAfrica.htm (Accessed 26 October 2009).

Talbot, I. 2007, 'The Punjab under Colonialism: Order and Transformation in British India,' Journal of Punjab Studies, vol. 14, no.1: 3-10.

Talbot, I. \& Thandi, S. 2004, People on the Move: Punjabi Colonial and Post-Colonial Migration. Oxford University Press, London.

Tatla, D.S. 1995, 'Sikh Free and Military Migration During the Colonial Period,' in The Cambridge Survey of World Migration, (ed.) Robin Cohen, Cambridge University Press, Cambridge, pp. 6973.

2004, 'The Rural Roots of the Sikh Diaspora,' in People on the Move: Punjabi Colonial, and PostColonial Migration, (eds) I. Talbot \& S. Thandi, Oxford University Press, London, 45-59.

Thandi, S. 2006, 'Punjabi Diaspora and Homeland Relations.' Online, available: http://www.indiaseminar.com/2006/567/567_shinder_s_thandi.htm (Accessed 23 October 2009).

'The $47^{\text {th }}$ (now the $5^{\text {th }}$ ) Regiment,' Jullundur Brigade Association. Online, available: www.jullundurassociation.org/index.php?option (Accessed 26 October 2009).

Thorburn, S.S. 1876, India Civil Service, Settlement Officer of the Bannu District. Bannu; or Our Afghan Frontier. Trtjbneit \& Co. 57 \& 59, Ludgate Hill, London.

Vandal, P.1846, The Illustrated London News, 28 March.

Wallerstein, I. 1974, The Modern World-System, vol. I: Capitalist Agriculture and the Origins of the European World-Economy in the Sixteenth Century. Academic Press, New York \& London.

Winstedt, R.O. 1934, 'History of Selangor,' J.M.B.R.A.S. vol. 12, in Lopo-Dhalliwal 1971, Some Historical Notes (Malaysian Sikhs). N.p., West Malaya.

Yong, T.T. 2005, The Garrison State: Military, Government and Society in Colonial Punjab, 1849-1947. Sage, Delhi.

Interviews

Inderjit Singh Gill;Hans Raj Aggarwal; Gurdial Singh Pandial; Mohinder Singh Chadha; Trilok Singh Nayer. Sikhs of East Africa. Online, available: www.sikhheritage.co.uk/heritage/sikhhert\%20EAfrica/sikhsEAfrica.htm (Accessed 26 October 2009).

Song

Surinder \& Parkash Kaur. 2004. Sadke sadke. Saregama. 